\title{
Stulecie Instytutu Biologii Doświadczalnej im. Marcelego Nenckiego PAN - siła idei i wola działania
}

\section{STRESZCZENIE}

$\mathbf{P}$ lacówka utworzona $\mathrm{z}$ inicjatywy trzech kierowników zakładów Towarzystwa Naukowego Warszawskiego: Kazimierza Białaszewicza, Romualda Minkiewicza i Edwarda Flataua, którzy w 1918 r. wystąpili z inicjatywą połączenia ich placówek w jedną, organizacyjną całość pod nazwą Instytut Biologii Doświadczalnej im. Marcelego Nenckiego. Istotny wpływ pozwalający na realizację tego celu miał wysoki legat złożony w 1909 roku przez najbliższą współpracowniczkę Nenckiego Nadieżdę Sieber-Szumową. W latach 1938-1939 Instytut tworzyły trzy zakłady: 1. Biologii Ogólnej, kier. Romuald Minkiewicz; 2. Fizjologii, kier. Kazimierz Białaszewicz; 3. Neurobiologii, kier. Kazimierz Orzechowski i trzy stacje terenowe: 1. Stacja Hydrobiologiczna nad Wigrami, kier. Alfred Lityński; 2. Stacja Morska na Helu, kier. Mieczysław Bogucki; 3. Stacja Biologiczna w Pińsku, kier. Jerzy Wiszniewski oraz Biblioteka, kier. Aniela Szwejcerowa. Drugą wojnę światową przeżyli Mieczysław Bogucki i Aniela Szwejcerowa. Materialnie zakłady, stacje terenowe i biblioteka przestały istnieć. Instytut został odbudowany od podstaw w Łodzi (1946-1956) i przeniesiony do nowej, zbudowanej w Warszawie siedziby przy ul. Pasteura 3. Szczególny wkład w jego odrodzenie wniosły trzy pary małżeńskie: Jan i Stanisława Dembowscy, Włodzimierz i Stella Niemierkowie, Jerzy Konorski i Liliana Lubińska. Instytut im. Nenckiego został upaństwowiony w 1946 roku, włączony do placówek Polskiej Akademii Nauk w roku 1952 i w tym też roku Rada Naukowa Instytutu nabyła uprawnienia do nadawania stopni naukowych doktora i doktora habilitowanego. Początkowo badania w Instytucie rozwijały się w kierunkach zapoczątkowanych w latach trzydziestych, następnie skoncentrowały się na aktywności i plastyczności mózgu, chorobach neurodegeneracyjnych związanych ze starzeniem, na funkcjach białek odpowiedzialnych za ruchy, roli jonów w tych procesach, transdukcji sygnałów, działaniach mitochondriów w normie i patologii, zjawiskach ruchliwości komórek, mechanizmach ekspresji genów, jak również sprawach związanych z chorobami neurodegeneracyjnymi, nowotworowymi i problemami starzenia. Instytut od lat wydaje i redaguje kwartalnik Acta Neurobiologiae Experimentalis i prowadzi zakrojoną na szeroką skalę akcję upowszechniania nauki skierowaną do dorosłych, młodzieży i dzieci. Po drugiej wojnie światowej Instytutem kierowali kolejno dyrektorzy: Jan Dembowski, Włodzimierz Niemierko, Jerzy Konorski, Kazimierz Zieliński, Maciej Jan Nałęcz, Jerzy Duszyński, Adam Szewczyk. Od lutego 2018 r. po raz pierwszy w stuletniej historii na czele Instytutu Nenckiego stoi kobieta, Agnieszka Dobrzyń.

Trudno dociec, kiedy u Marcelego Nenckiego zrodziła się idea utworzenia w Warszawie instytutu biologiczno-medycznego. Nie ma natomiast wątpliwości, że w okresie jego pobytu w Petersburgu była tematem podnoszonym wielokrotnie w gronie osób z Wydziału Chemii Instytutu Medycyny Doświadczalnej, którym w latach 1891-1901 kierował Marceli Nencki. Po jego śmierci, 14 października 1901 roku, sprawę podjęli najbliżsi jego współpracownicy, Nadina (Nadieżda) Sieber-Szumowa i Jan Zalewski.

Pod zaborem rosyjskim realizacja tego pomysłu okazała się niemożliwa do spełnienia. Wśród uczniów Nenckiego byli jednak ludzie niezłomni, którzy mieli wolę działania i dysponowali znacznymi środkami pieniężnymi.

Taką osobą była Nadina Sieber-Szumowa, która 27 kwietnia 1909 r. złożyła na ręce działających w Warszawie Antoniego Ossuchowskiego i barona Kazimierza Lessera legat $\mathrm{w}$ wysokości 50.000 rubli w złocie z przeznaczeniem na utworzenie pracowni badawczych w Warszawie pod nazwą „Instytut Nauk Biologicznych im. Marcelego Nenckiego". Nadina Sieber-Szumowa zmarła 16 maja 1916 r. mając uzasadnione nadzieje, że projekt utworzenia placówki im. Marcelego Nenckiego zostanie zrealizowany. Nie było to bezpodstawne. 27 października $1911 \mathrm{r}$. Zarząd Towarzystwa Naukowego Warszawskiego (TNW) podjął uchwałę o założeniu Instytutu Biologicznego im. Marcelego Nenckiego. Do jej realizacji doszło dopiero po siedmiu latach.

W 1918 r. trzej kierownicy zakładów TNW: Kazimierz Białaszewicz, Edward Flatau i Romuald Minkiewicz zwrócili się do Zarządu TNW z inicjatywą połączenia prowadzonych przez nich jednostek $\mathrm{w}$ jedną organizacyjną całość pod nazwą "Instytut Biologii Doświadczalnej im. Marcelego Nenckiego". W 1919 r.

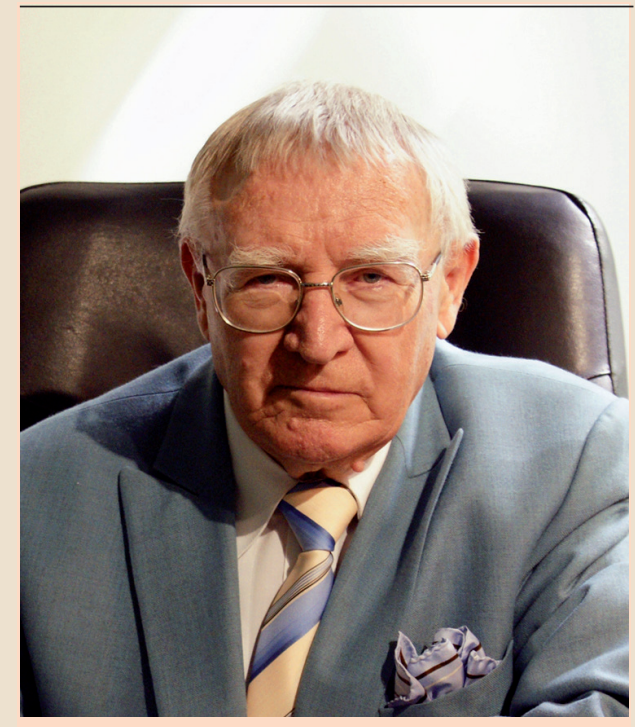

Profesor Leszek Kuźnicki

\section{Leszek Kuźnicki ${ }^{\bowtie}$}

Pracownia Cytoszkieletu i Biologii Rzęsek, Instytut Biologii Doświadczalnej im. Marcelego Nenckiego PAN, Warszawa

Pracownia Cytoszkieletu i Biologii Rzęsek, Instytut Biologii Doświadczalnej im. Marcelego Nenckiego PAN, ul. Pasteura 3, 02 093 Warszawa; e-mail: 1.kuznicki@nencki.gov. $\mathrm{pl}$

Artykuł otrzymano 16 lipca 2018 r. Artykuł zaakceptowano 18 lipca 2018 r.

Słowa kluczowe: historia, Instytut Nenckiego 
Tabela 1. Struktura i skład osobowy Instytutu Biologii Doświadczalnej im. Marcelego Nenckiego w latach 1938-1939 Zakład Biologii Ogólnej

\begin{tabular}{|c|c|}
\hline Kierownik: & Romuald Minkiewicz \\
\hline Asystenci: & Zygmunt Czerniewski, Wiktor Nowiński, Henryk Teleżyński \\
\hline \multicolumn{2}{|l|}{ Zakład Fizjologii } \\
\hline Kierownik: & Kazimierz Białaszewicz \\
\hline Asystentki: & Liliana Lubińska, Genowefa Szwejkowska \\
\hline \multicolumn{2}{|l|}{ Zakład Neurobiologii } \\
\hline Kierownik: & Kazimierz Orzechowski \\
\hline Zastępca: & Władysław Jakimowicz \\
\hline Laborantka: & Zofia Szymalska \\
\hline \multicolumn{2}{|c|}{ Stacja Hydrobiologiczna nad Wigrami } \\
\hline Kierownik: & Alfred Lityński \\
\hline Adiunkt: & Zygmunt Koźmiński \\
\hline Asystent: & Kazimierz Passowicz \\
\hline Laborant: & Włodzimierz Wasylenko \\
\hline \multicolumn{2}{|l|}{ Stacja Morska na Helu } \\
\hline Kierownik: & Mieczysław Bogucki \\
\hline Starszy asystent zoolog: & Kazimierz Demel \\
\hline Młodsi asystenci ichtiologowie: & Walerian Cięglewicz, K. Posadzki, Zygmunt Mulicki \\
\hline Młodszy asystent algolog: & Adam Bursa \\
\hline Hydrograf: & Stanisław Kijowski \\
\hline Planktolog: & Władysław Mańkowski \\
\hline \multicolumn{2}{|c|}{ Poleska Stacja Biologiczna w Pińsku } \\
\hline Kierownik: & Jerzy Wiszniewski \\
\hline \multicolumn{2}{|l|}{ Biblioteka Instytutu } \\
\hline Bibliotekarka: & Aniela Szwejcerowa \\
\hline
\end{tabular}

stał profesorem University of California, Berkley i na stałe wyjechał z Polski.

„Osoby prowadzące badania w Instytucie Nenckiego w latach 1918-1939 należały do czterech grup: 1. Kierownicy zakładów badawczych; 2. Asystenci starsi i asystenci młodsi; 3. Laboranci; 4. Pracownicy (współpracownicy). Rok 1920 był pierwszym rokiem sprawozdawczym. Stała kadra placówki składała się wówczas z trzech kierowników (K. Białaszewicz, R. Minkiewicz, A. Lityński), czterech asystentów (T. Vieweger, T. Klimowicz, R. Szreter, J. Dembowski) i dwóch laborantek (S. Dembowskiej i Z. Krasińskiej). Łącznie dziewięć osób. Liczniejszą była grupa "pracowników", którzy faktycznie nie byli z Instytutem związani żadnymi stosunkami pracy. We wszystkich kategoriach

Zarząd TNW przychylił się do tej inicjatywy. 30 maja 1920 r. ukonstytuowało się Prezydium Instytutu, którego przewodniczącym został Kazimierz Białaszewicz. I tak, dzięki sile idei i woli działania wielu osób, marzenia Nenckiego stały się rzeczywistością.

Towarzystwo Naukowe Warszawskie zamierzało w latach dwudziestych powołać sześć placówek poświęconych różnym dziedzinom. Powstały dwie, trwałą strukturą okazał się Instytut im. Marcelego Nenckiego. Było to zaskakujące, gdyż w latach 1920-1939 Instytut działał w oparciu o tymczasowy statut. Środki państwowe na inwestycje były kierowane tylko na stacje terenowe na Wigrach, na Helu i w Pińsku. Kadrowo Instytut pozostawał placówką nieliczną, mimo to jego oddziaływanie na środowisko biologów w Polsce i poza jej granicami było znaczące ${ }^{1}$.

Przez dziesięć lat (1928-1937) jednostką Instytutu był Zakład Biometrii prowadzony przez Jerzego Spławę Neymana, który jednocześnie był profesorem i kierownikiem Zakładu Statystyki Matematycznej Szkoły Głównej Gospodarstwa Wiejskiego w Warszawie. Rozdział zadań, którego bardzo przestrzegał był prosty: teoria statystyki - Nencki, rozwiązywanie zadań praktycznych - SGGW. W okresie 1928-1934 Jerzy Neyman samodzielnie i przy współpracy z Egonem S. Pearsonem stworzył podstawy i określił kierunki rozwoju statystyki matematycznej. Wśród wielu rozwiązań Neyman, dla wnioskowania o poprawności hipotez, wprowadził „podziały ufności”. W roku 1938 Jerzy Neyman zo-

\footnotetext{
${ }^{1}$ L. Kuźnicki: Instytut Biologii Doświadczalnej im. Marcelego Nenckiego. Historia i teraźniejszość. T 1. 1918-2007. Warszawa 2008.
}

przepływ ludzi przez zakłady badawcze oraz stacje był duży, w szczególności dotyczyło to pracowników. Pobyt roczny, dwuletni, czy nawet dłuższy w Instytucie, dzięki zaangażowaniu kierowników i asystentów oraz możliwości logistyczne placówki, stwarzały warunki do wykonania badań wręcz niemożliwych na uczelniach.

Z tych możliwości korzystali uczeni o uznanej pozycji ze stopniami doktora i docenta, jak również młodzież, która pobyt w Nenckim wykorzystywała do badań będących podstawą rozprawy doktorskiej, którą broniła na Uniwersytecie Warszawskim. Do tej grupy należeli między innymi Antoni Dmochowski, Stella Saks (Niemierkowa), Maksymilian Chejfec" ${ }^{\prime 2}$. Łącznie w okresie dwudziestoletnim w placówkach Instytutu Nenckiego prowadziło badania i szkoliło się około 200 osób. Według Nawroczyńskiego ${ }^{3}$ w latach 1938-1939 stała kadra Instytutu liczyła 24 osoby (Tab. 1).

Podobnie jak przy utworzeniu Instytutu, na sukces okresu 1920-1939 złożyły się te same czynniki, które warunkowały jego powstanie - siła idei i wola działania na rzecz rozwoju nauki osób, które zaangażowały się w jego rozwój. Przede wszystkim współtwórcy Instytutu Kazimierza Białaszewicza (1882-1943), który w latach 1918-1939 umiejętnie łączył prowadzenie Zakładu Fizjologii w Instytucie Nenckiego z pracą profesora Uniwersytetu Warszawskie-

\footnotetext{
${ }^{2}$ Tamże.

${ }^{3}$ B. Nawroczyński: Towarzystwo Naukowe Warszawskie. Materiały do jego dziejów w latach 1907-1950. Warszawa 1950, s. 76-77.
} 
go, w którym kierował Zakładem Fizjologii Zwierząt. Oba zakłady miały wspólne lokale, początkowo na ulicy Śniadeckich $8 \mathrm{w}$ gmachu TNW, a po wybudowaniu Instytutu Radowego na jego terenie przy ulicy Wawelskiej.

Znaczący wkład w rozwój Nenckiego miał również Romuald Minkiewicz (1878-1944) kierownik Zakładu Biologii Ogólnej, jednocześnie aktywny literat.

W latach 1918-1939 najbardziej rozbudowanymi strukturami Instytutu były jego stacje terenowe: Stacja Hydrobiologiczna nad Wigrami (1920-1939), stworzona i prowadzona przez Alfreda Lityńskiego, Stacja Morska na Helu (19321939) kierowana przez Mieczysława Boguckiego oraz zbudowana przez Jerzego Wiszniewskiego Stacja Rzeczna w Pińsku (1937-1939). Stacje te odegrały szczególną rolę jako ośrodki umożliwiające prace badawcze $\mathrm{w}$ terenie i kształcenie młodzieży z całej Polski, w czym największy udział mieli ich kierownicy.

Instytut im. Marcelego Nenckiego jest jednym z wielu przykładów tragicznych i niszczycielskich następstw II wojny światowej na ziemiach polskich. Wśród założycieli i kierowników zakładów Instytutu ocalał tylko Mieczysław Bogucki. W okresie od 1 września 1939 r. do 8 maja 1945 r. zmarli, zginęli w walce, zostali zamęczeni: Kazimierz Białaszewicz, Alfred Lityński, Romuald Minkiewicz, Kazimierz Orzechowski i Jerzy Wiszniewski, kierownicy wszystkich zakładów i dwóch stacji. Równie ciężkie i bolesne straty dotyczyły grona osób, które nie były na stałe związane $\mathrm{z}$ "Nenckim", tylko prowadziły badania w zakładach i stacjach Instytutu.

Materialnie placówka przestała istnieć. Pomieszczenia zajmowane przez Instytut $\mathrm{w}$ budynku na Śniadeckich $8 \mathrm{i}$ przy Wawelskiej zostały zrujnowane, biblioteka spłonęła. Stację nad Wigrami rozgrabiono, Stacja w Pińsku znalazła się poza granicami Polski. Stację Morską, którą w 1939 r. przeniesiono do Gdyni, włączono do Morskiego Instytutu Rybackiego. Ci nieliczni, którzy wojnę przeżyli, nie mieli do czego wracać.

Wiosną 1945 r. w gronie sześciu osób tworzących trzy rodziny, Jana i Stanisławy Dembowskich, Włodzimierza i Stelli Niemierków oraz Jerzego Konorskiego i Liliany Lubińskiej, zrodziła się wola odbudowy Instytutu. Równie istotną sprawą była strategia działań. Instytut powinien zostać odtworzony w Warszawie, w najkrótszym terminie jaki tylko będzie możliwy. Do tego czasu należało prowadzić badania i odtworzyć kadrę naukową, tam gdzie będą ku temu korzystne warunki. Powojenni pionierzy wybrali Łódź, której zniszczenia wojenne nie dotknęły. Nie bez znaczenia był też fakt, że wśród szóstki inicjatorów odbudowy Jerzy Konorski, Stella Niemierko i Liliana Lubińska byli łodzianami.

Kolejne wydarzenia miały równie istotne znaczenia warunkujące powodzenie akcji. 1 kwietnia $1946 \mathrm{r}$. Instytut Nenckiego został upaństwowiony. $W$ tym czasie był strukturą złożoną z trzech jednostek: Zakładu Biochemii kierowanego przez Włodzimierza Niemierkę, Zakładu Neurofi- zjologii prowadzonego przez Jerzego Konorskiego i Biblioteki odtwarzanej przez Anielę Szwejcerową.

W listopadzie 1947 r. powrócili z Moskwy Jan i Stanisława Dembowscy. Profesor Dembowski został dyrektorem Instytutu i przystąpił do odbudowy Zakładu Biologii, którym do września 1939 r. kierował Romuald Minkiewicz.

Na zaproszenie Tadeusza Kotarbińskiego wszyscy trzej kierownicy zakładów w Nenckim, jak również Stella Niemierko i Stanisława Dembowska, zostali pracownikami Uniwersytetu Łódzkiego. To ułatwiało kontakt z młodzieżą akademicką. Mimo ograniczonej powierzchni, szczególnie intensywny proces kształcenia młodego pokolenia badaczy miał miejsce przede wszystkim na terenie tymczasowej siedziby Instytutu w Łodzi, przy ulicy Południowej 66.

W pierwszych latach powojennych szereg czynników sprzyjało szybkiej odbudowie placówki. Przede wszystkim autorytet i pozycja Jana Dembowskiego. Jego starania spowodowały podjęcie już w 1949 r. działań na rzecz odbudowy siedziby Instytutu w Warszawie.

W miejscu zaplanowanym przez Kazimierza Białaszewicza w latach trzydziestych, na obszarze 1ha między ulicami Marii Skłodowskiej-Curie i Louisa Pasteura powstały w latach 1950-1953 dwa budynki, główny 5-poziomowy oraz jednopiętrowy przeznaczony na zwierzętarnię, warsztaty i kompleks mieszkalny.

W 1951 r. Instytut powołał Stację Hydrobiologiczną w Mikołajkach, podobnie jak stacje przedwojenne, otwartą dla badaczy z całej Polski i nie tylko biologów. Jej kierownikiem został Andrzej Szczepański, który wraz z żoną Wandą podjął pionierską działalność na obszarze Wielkich Jezior Mazurskich. Przedwojenna struktura Instytutu, choć w ograniczonym zakresie, została odtworzona.

W 1952 r. rozpoczęła działalność Polska Akademia Nauk. Jej pierwszym prezesem został Jan Dembowski, a Instytut Nenckiego został do niej włączony, jako jedna z placówek. Ta decyzja miała korzystny wpływ na jego rozwój - przede wszystkim ułatwiła w latach 1953-1956 przenoszenie pracowników Instytutu z Łodzi do Warszawy.

1 stycznia 1953 r. w Nenckim zatrudnionych było 70 osób wśród nich 9 profesorów i docentów, 35 adiunktów, starszych asystentów i asystentów.

Lata przenosin do Warszawy (1953-1956) to okres zmian strukturalnych i szybkich przyrost liczby pracowników. W 1953 r. został utworzony Zakład Hydrobiologii Eksperymentalnej, którego kierownictwo objął Romuald Klekowski. W dwa lata później Zakład Psychologii, na którego czele stanął Eugeniusz Geblewicz. W 1956 r. utworzono w Instytucie Pracownię Izotopową, kierowaną przez Irenę Kąkol.

Ten dynamiczny rozwój został nagle zahamowany. Na Zgromadzeniu Ogólnym Polskiej Akademii Nauk, które obradowało w dniach 11 i 12 czerwca 1956 r. poddano krytycznej ocenie uległość kierownictwa Akademii wobec Wydziału Nauki KC PZPR i bezkrytyczne przyjmowanie błędnych 
koncepcji łysenkizmu. W konsekwencji, Jan Dembowski i całe Prezydium PAN podało się do dymisji.

Dla Instytutu Nenckiego miało to szereg następstw hamujących jego rozwój. Zatrzymano środki inwestycyjne. W konsekwencji odstąpiono od budowy sali konferencyjnej, a nawet zaniechano na kilkanaście lat wykonanie prac tynkarskich, budowy dróg wewnętrznych i ogrodzenia terenu. Te zaniechania były wynikiem działań nowego kierownictwa PAN, niechętnego profesorowi Dembowskiemu.

Zmiany, które miały miejsce w Polsce w październiku 1956 r. wyzwoliły kraj z pęt stalinizmu. Dla nauki szczególnie istotne było "otworzenie się Polski na Zachód”, co między innymi oznaczało rozwój współpracy międzynarodowej, przede wszystkim możliwości wyjazdów na długie staże do silnych ośrodków naukowych w Europie Zachodniej, Stanach Zjednoczonych i Kanadzie. Środowisko "Nenckiego" szeroką falą z tego skorzystało. Nie wszyscy, którzy wyjechali, powrócili do kraju. Rozwój współpracy miał różne formy.

Prof. Jerzy Konorski w 1958 r. zorganizował w Osiecznej koło Poznania konferencję trzech instytutów: „Nenckiego", Instytutu Wyższych Czynności Nerwowych i Neurofizjologii w Moskwie i Instytutu Fizjologii w Pradze. Spotkanie to zapoczątkowało osiem kolejnych konferencji w różnych krajach europejskich pod nazwą „Conferences of the Three Institutes".

Kreśląc historię Instytutu okres 1957-1967 nazwałem „Trudne lata”.

„W dniu 13 września Rada Ministrów wydała rozporządzenie wprowadzające powszechny w Polsce obowiązek przejścia na emeryturę dla wszystkich pracujących w szkolnictwie wyższym, w placówkach PAN i instytutach branżowych, którzy ukończyli siedemdziesiąty rok życia. Rozporządzenie wprowadziło też zasadę jednoetatowości. W całym obszarze szkolnictwa wyższego i nauki wolno było pracować tylko w jednym miejscu.

Rozporządzenie miało dwa cele: oczywisty oszczędnościowy i polityczny - odsunięcia od wpływów starej przedwojennej grupy profesorów, którzy w większości kontestowali działania władz komunistycznych. W Instytucie Nenckiego rozporządzenie dotyczyło Jana Dembowskiego i Mieczysława Boguckiego.

Od 1 stycznia 1961 r. Jan Dembowski, mając 71 lat przestał być dyrektorem Instytutu i kierownikiem Zakładu Biologii. Na czele Instytutu stanął Włodzimierz Niemierko. Zakład Biologii od czerwca 1961 r. objął Stanisław Dryl.

Nastąpiły nie tylko zmiany personalne w Instytucie, ale również ograniczenia lokalowe. Decyzją administracyjną Sekretarza Naukowego, uzgodnioną z Sekretarzem Wydziału II, zmniejszono Instytutowi powierzchnię laboratoryjną. W gmachu głównym przy ul. Pasteura 3 od 1961 roku znalazły swoją główną siedzibę Zakład Parazytologii, Zakład Geofizyki oraz pojedyncze zakłady Centrum Medycyny Doświadczalnej i Klinicznej oraz Biochemii i Biofizyki.
W konsekwencji uszczuplono Instytut Nenckiego o około $1000 \mathrm{~m}^{2}$. Decyzja ta miała dalekosiężne negatywne konsekwencje. Ostatni sublokator - Instytut Parazytologii wyprowadził się w roku 1997.

Mimo różnych, kłopotliwych następstw towarzyszących zagęszczeniu przy ul. Pasteura 3 różnych placówek Akademii, przez wszystkie lata stosunki zarówno między kierownictwami, jak i pracownikami gospodarzy i lokatorów pozostawały na stopie koleżeńskiej. Siedziba "Nenckiego" sprzyjała przyjaźni.

W 1962 roku Stacja Hydrobiologiczna w Mikołajkach została przekazana Zakładowi Ekologii PAN, zaś rok wcześniej Zakład Psychologii Eksperymentalnej oddano Uniwersytetowi Warszawskiemu. Powody oddzielenia Instytutu Nenckiego były w obu przypadkach różne. Profesor Eugeniusz Geblewicz obciążony pracą w kilku miejscach, w Instytucie nie podjął żadnej działalności. Jednocześnie rozporządzenie z 13 września 1960 r. zmuszało go do wyboru jednego miejsca pracy" ${ }^{4}$.

„Największym niebezpieczeństwem dla przyszłości Instytutu były plany reorganizacyjne, uparcie lansowane przez Kazimierza Petrusewicza w latach 1952-1956 i ponownie w okresie 1963-1968 Sekretarza Wydziału II Nauk Biologicznych PAN. Żywił on głębokie przekonanie, co ważniejsze usiłował je zrealizować, że dla dobra rozwoju nauki należy przenieść Zakład Biochemii z Instytutu Nenckiego do Instytutu Biochemii i Biofizyki PAN. Gdy w roku 1967 powstało Centrum Medycyny Doświadczalnej i Klinicznej PAN w wyniku połączenia sześciu zakładów Akademii Medycznej, Petrusewicz uważał, że powinien tam się znaleźć również Zakład Neurofizjologii. Planu rozparcelowania Instytutu Nenckiego nie udało się profesorowi Petrusewiczowi zrealizować, gdyż nikt z partnerów, którzy mieli uczestniczyć w fuzji, nie podzielał jego poglądów. Przekazanie Stacji Hydrobiologicznej było gestem dobrej woli na rzecz prowadzonego przez niego Zakładu Ekologii.

Można uważać za paradoks, że okres 1957-1967, który nazwałem >>trudne lata<< przyniósł we wszystkich kierunkach badań uprawianych w Instytucie ogromny postęp i wzrost znaczenia na arenie międzynarodowej. Właśnie w tym okresie już nie poszczególni ludzie, ale Instytut jako centrum badawcze został dostrzeżony za granicą jako ośrodek, z którym warto nawiązać długotrwałą współpracę.

Taki charakter miała umowa z 1962 r. między Zakładem Neurofizjologii reprezentowanym przez Jerzego Konorskiego, a sekcją neuropsychologii National Institute of Mental Health w Bethesda reprezentowanym przez H. E. Rosvolda. Na podstawie tej umowy badania prowadzone w Instytucie Nenckiego, które interesowały stronę amerykańską były finansowane za polskie złotówki jako forma spłaty tzw. $>$ >długu zbożowego <<, zaciągniętego przez PRL w USA. Tak pozyskane środki $\mathrm{w}$ ramach $>>$ Public Low - PL $480<<$ można było przeznaczyć na wyposażenie i odczynniki, zlecenia i dopłaty oraz honoraria dla poszczególnych osób zaangażowanych w badania objęte umową. Parę lat później

${ }^{4}$ L. Kuźnicki: Instytut Biologii Doświadczalnej im. Marcelego Nenckiego. Historia i Teraźniejszość. Tom 1. 1918-2007. Warszawa 2008, s. 98-99. 
podobną umowę zawarł Witold Drabikowski z Johnem Gergelym z Bostońskiego Instytutu Badań Biomedycznych $\mathrm{w}$ Bostonie na prace $\mathrm{z}$ zakresu biochemii mięśni. Znaczenie środków z >>PL 480<< polegało przede wszystkim na tym, że można je było wykorzystać na cele, na które pieniądze z budżetu były ograniczone i limitowane, jak choćby wyjazdy za granicę.

Sumując, trudne lata, jakie nastąpiły po roku 1956 przyczyniły się do zwarcia szeregów w Instytucie i wejścia szerokim frontem $\mathrm{w}$ pole nowoczesnych badań uprawianych w świecie.

Uzasadnione przekonanie o wartościowych dokonaniach naukowych i dydaktycznych skłoniło Radę Naukową do podjęcia uchwały w sprawie uroczystych obchodów 50-lecia Instytutu ${ }^{5}$ W uchwale podkreślono wysoką wydajność wyrażającą się dużą liczbą publikacji rocznie, rozbudowaną współpracą międzynarodową, obejmującą również długoterminowe staże cudzoziemców w Instytucie oraz zwrócono uwagę na osiągnięcia $\mathrm{w}$ zakresie kształcenia. W ciągu dwudziestu lat 51 pracowników uzyskało stopień doktora, 21 stopień docenta, z których 7 otrzymało następnie tytuł profesora. Ponadto $\mathrm{w}$ Instytucie przeprowadzono przewody doktorskie i habilitacyjne kilkudziesięciu osób spoza Instytutu. Księgozbiór Biblioteki z powojennej pozycji zerowej przekroczył 50.000 woluminów. Dzięki regularnemu wydawaniu trzech czasopism (Acta Biologiae Experimentalis, Acta Protozoologica, Polskie Archiwum Hydrobiologii) Instytut otrzymywał w drodze wymiany czasopisma z 950 placówek z 65 krajów" ${ }^{\prime \prime}$.

Drugie półwiecze działalności Instytutu im. M. Nenckiego (1969-2018) różniło się istotnie od pierwszego. Przede wszystkim nie było $\mathrm{w}$ nim tak dramatycznych wydarzeń, jakim była II wojna światowa i jej niszczycielskie następstwa. Wydarzenia polityczne oczywiście rzutowały na jego historię, ale ich wpływ na dzieje był innej skali.

„Dla przyszłości Instytutu im. M. Nenckiego szczególne znaczenie miały zmiany struktury organizacyjnej, które nastąpiły w roku 1971. Były one podyktowane zarówno czynnikami zewnętrznymi jak i wewnętrznymi. Z dniem 1 stycznia 1971 roku zmieniono system organizacji i finansowania nauki w Polsce. Dotychczas stosowane finansowanie podmiotowe, czyli placówek, zastąpiono finansowaniem przedmiotowym. Środki na prowadzenie badań naukowych nie były kierowane bezpośrednio do instytutów czy uczelni lecz do koordynatorów 5-letnich problemów badawczych. Problemy te były nie tylko zróżnicowane tematycznie, ale też miały różną hierarchię $\mathrm{w}$ zależności od przyjętego znaczenia praktycznego bądź poznawczego. W ramach poszczególnych problemów jednostki lub zespoły badawcze z różnych uczelni czy instytutów, które zajmowały się zbieżną bądź komplementarną tematyką miały ze sobą współpracować. W nowym systemie pieniądze na badania Instytut otrzymywał z różnych źródeł, a osoby pracu-

\footnotetext{
${ }^{5}$ Uchwała z dnia 1 kwietnia 1967 r. miała siedem stron maszynopisu i była skierowana do Prezydium Polskiej Akademii Nauk. W uchwale zamieszczono program uroczystości, liczbę zaproszonych gości z zagranicy na proponowane sympozja, propozycje wydawnicze oraz merytoryczne uzasadnienie obchodów.

${ }^{6}$ L. Kuźnicki: Instytut ... dz. cyt., s. 100-102.
}

jące w danym zakładzie mogły działać w odrębnych problemach, jak również ten sam zespół mógł otrzymywać środki z różnych źródeł"7.

Zmianom systemowym organizacji i finansowania nauki w Polsce towarzyszyły przekształcenia organizacyjne w „Nenckim”. „Postanowiono, że z dniem 1 stycznia 1971 pracownie stają się elementarnymi, merytorycznymi i organizacyjnymi jednostkami w Instytucie oraz, że będą pełnić funkcję wykonawcy jednostkowych zadań $\mathrm{w}$ ramach problemów. Było to odstępstwo od dotychczasowej tradycji Instytutu. $>>$ Nencki<< powstał zgodnie ze statutem Towarzystwa Naukowego Warszawskiego jako federacja zakładów. Mimo, że odrodził się w Łodzi już na zupełnie innych zasadach prawnych i organizacyjnych, federacjonizm był postrzegany i ustnie głoszony.

Pierwszym wyłomem w tej tradycji był podział Zakładu Biochemii, który nastąpił w roku 1970 . Okazało się, że dwie indywidualności - Lech Wojtczak i Witold Drabikowski, po odejściu na emeryturę Włodzimierza Niemierki, nie potrafiły ułożyć współpracy w obrębie jednej struktury. Na miejsce Zakładu Biochemii powstały dwa: Zakład Biochemii Komórki na czele którego stanęła Zofia Zielińska i Zakład Biochemii Układu Nerwowego i Mięśni pod kierownictwem Witolda Drabikowskiego. Zaistniały rozdział okazał się trwały. W Instytucie Zakład Biochemii został ponownie ustanowiony dopiero $\mathrm{w}$ roku $2007 \mathrm{i}$ to $\mathrm{z}$ powodu daleko posuniętego uwiądu Zakładu stworzonego przed 37 laty przez Drabikowskiego"8.

Dokonano też innych zmian strukturalnych. "Zakład Biologii zmienił nazwę na Zakład Biologii Komórki. Wchodząca w jego skład Pracownia Etologii Zwierząt została rozwiązana, a jej pracownicy przeniesieni do dwóch różnych pracowni w Zakładzie Neurofizjologii. Zakład Hydrobiologii Eksperymentalnej dostosował nazwę do nowej problematyki badawczej i stał się Zakładem Energetyki i Produkcji Biologicznej"9.

„W pierwszej połowie lat 70. Instytut im. M. Nenckiego przeszedł dwa kolejne przekształcenia strukturalne. $\mathrm{W}$ 1972 r. przejął Zakład Hodowli Zwierząt Laboratoryjnych w Łomnie, będący dotychczas samodzielną placówką Polskiej Akademii Nauk, zaś z dniem 1 stycznia 1975 r. Zakład Energetyki i Produkcji Biologicznej został przeniesiony z Instytutu Nenckiego do Instytutu Ekologii PAN"10.

„Po trzynastu latach od przejęcia dyrektor Instytutu im. M. Nenckiego Kazimierz Zieliński spowodował, że Zakład Hodowli Zwierząt Laboratoryjnych $\mathrm{w}$ Łomnie stał się ponownie samodzielną placówką pomocniczą Polskiej Akademii Nauk. Cała sprawa okazała się wręcz epizodem nieważącym na historii warszawskiego centrum badawczego"11.

Z początkiem roku 1974 została utworzona w Instytucie przez Aleksandrę Przełęcką Pracownia Mikroskopii Elektronowej. Pierwszym jej kierownikiem był Andrzej Dut-

\footnotetext{
${ }^{7}$ Tamże, s. 148.

${ }^{8}$ Tamże, s. 148-149.

${ }^{9}$ Tamże, s. 149.

${ }^{10}$ Tamże.

${ }^{11}$ Tamże, s. 150.
} 
kowski. Po jego śmierci Pracownię przejęła i prowadziła z powodzeniem do 2018 r. Elżbieta Wyroba.

Lata siedemdziesiąte i osiemdziesiąte charakteryzowały się zaangażowaniem Instytutu Nenckiego w organizację międzynarodowych imprez dużej wagi.

W 1972 r. odbyła się w Jabłonnie konferencja pt. „Brain and Behavior I", która zapoczątkowała kolejne dotyczące tej tematyki.

„W 1973 r. z inicjatywy Witolda Drabikowskiego, przy czynnym udziale Hanny Strzeleckiej-Gołaszewskiej odbyło się w Jabłonnie sympozjum pt. >>International Symposium on Calcium Binding Proteins $<<$, które zapoczątkowało regularne spotkania specjalistów z tego zakresu, trwające do chwili obecnej"12.

„W dniach 5-11 lipca 1981 odbył się w Warszawie >>VI International Congress of Protozoology $<<$. Miejscem obrad był budynek Akademii Muzycznej im. F. Chopina przy ul. Okólnik 2. Była to największa impreza naukowa, jaką od swego powstania zorganizował samodzielnie Instytut. Przewodniczącym Kongresu był Stanisław Dryl, wiceprzewodniczącym i przewodniczącym sekcji naukowych Leszek Kuźnicki, sekretarzem Stanisław L. Kazubski, sekretarzem wykonawczym Elżbieta Wyroba. Pokłosiem Kongresu były dwa specjalne zeszyty >>Acta Protozoologica<< 1982 i 1984, zatytułowane Progress in Protozoology. Proceedings of VI International Congress of Protozoology"13.

„13 grudnia 1981 r. premier i I sekretarz KC PZPR generał Wojciech Jaruzelski ogłosił wprowadzenie w Polsce stanu wojennego. NSZZ >>Solidarność<< został zdelegalizowany. Tysiące osób internowano, wprowadzono kontrolę poruszania się poza miejscami zamieszkania. Początkowo wyłączono telefony, a następnie wprowadzono oficjalny podsłuch. Zawieszono działalność Zgromadzenia Ogólnego PAN, w następstwie czego nie odbyło się Zgromadzenie Ogólne przewidziane na 19 grudnia, ani też dwa kolejne, które zgodnie z dotychczasową tradycją powinny się odbyć w 1982 roku. Początkowo wstrzymano, a następnie ograniczono wyjazdy za granicę, w szczególności długookresowe. Wprowadzono >>Instrukcję wyjazdową<<, bez której podpisania nie można było uzyskać paszportu. Instrukcja między innymi zobowiązywała do >>aktywnego reprezentowania politycznych i gospodarczych interesów $\mathrm{PRL}<<$. Do PAN wprowadzono komisarza wojennego, którym został gen. bryg. dr Rudolf Dżipanov. Zawieszono wydawanie czasopism i organizowanie posiedzeń towarzystw naukowych"14.

W Instytucie Nenckiego „podziemna >>Solidarność<< zorganizowała 13 kwietnia 1982 r., w cztery miesiące po ogłoszeniu stanu wojennego, protest. O godzinie 12:00 przerwało pracę około 100 osób i w milczeniu zgromadziło się na kilka minut na parterze w holu i bocznych korytarzach. Następstwem tego wydarzenia było osadzenie do 31 lipca 1983 w Instytucie ppłk Stanisława Boguckiego oraz

\footnotetext{
${ }^{12}$ Tamże, s. 43.

${ }^{13}$ Tamże, s. 46

${ }^{14}$ Tamże, s. 48
}

indywidualne przesłuchania prowadzone przez Kazimierza Zielińskiego z zespołem (Bogusław Żernicki, Stanisław Bogucki, Władysław Dąbrowski), które jednak nie miały dla nikogo żadnych negatywnych następstw"15.

Lata osiemdziesiąte zapoczątkowały proces „przejmowania" Instytutu przez kolejne pokolenie badaczy. Po nagłej i niespodziewanej śmierci Witolda Drabikowskiego (1983) kierownikiem Zakładu Biochemii Układu Nerwowego i Mięśni została Hanna Strzelecka-Gołaszewska. Po ustąpieniu Stanisława Dryla kierownictwo Zakładu Biologii Komórki objęła Maria Jerka-Dziadosz.

W roku 1984 przewodniczącym Rady Naukowej Instytutu został Andrzej Grębecki, profesor z powojennego pokolenia. Pojawiły się nowe struktury mające wpływ na rozwój Instytutu.

„Utworzono Laboratorium Hodowli Komórek i Tkanek pod kierownictwem Leszka Kaczmarka. Laboratorium istniało do roku 1996, kiedy to zostało wcielone do nowopowstałego Zakładu Neurobiologii Molekularnej i Komórkowej"16.

„Między 6 lutego i 5 kwietnia miały miejsce w Warszawie w Pałacu Namiestnikowskim (obecnie Prezydenckim) obrady Okrągłego Stołu między będącą u władzy stroną partyjno-rządową, a przedstawicielami dotychczas nielegalnej opozycji. Podczas obrad uzgodniono ponowne zarejestrowanie NSZZ >>Solidarność<< oraz przeprowadzenie częściowo ograniczonych wyborów do Sejmu, a także - w pełni demokratycznych wyborów do Senatu. 4 czerwca odbyły się wybory do Parlamentu, które przyniosły zwycięstwo opozycji. Datę tę uznaje się za początek odzyskania przez Polskę suwerenności"17.

Pełne przejęcie kierownictwa Instytutu przez kolejne pokolenie nastąpiło w roku 1991. „Maciej Nałęcz został dyrektorem Instytutu, zastępując na tym stanowisku Kazimierza Zielińskiego, który kierował Instytutem Nenckiego nieprzerwanie od jesieni 1973 r. Kierownikiem Zakładu Biologii Komórki została Ewa Mikołajczyk, zastępując na tym stanowisku Marię Jerkę-Dziadosz. Andrzej Wróbel przejął od Bogusława Żernickiego redakcję >>Acta Neurobiologiae Experimentalis $<<" 18$.

„Kierownikiem Biblioteki Instytutu został Jan Bienias. Henryk Adler, który zajmował to stanowisko od 1960 roku przeszedł na emeryturę"19.

Rok 1991 zapoczątkował kolejne lata sukcesów ludzi z Instytutu im. Marcelego Nenckiego, którym towarzyszył rozwój samej placówki. Zadecydowało o tym szereg czynników. Sprawność i umiejętność rządzenia kolejnych dyrektorów: Macieja Nałęcza (1991-2001), Jerzego Duszyńskiego (2001-2010), Adama Szewczyka (2011-2018). Kompetencje

\footnotetext{
${ }^{15}$ Tamże, s. 49.

${ }^{16}$ Tamże, s. 50 .

${ }^{17}$ Tamże, s. 50-51.

${ }^{18}$ Tamże.

${ }^{19}$ Tamże, s. 52
} 
i zaangażowanie przewodniczących Rady Naukowej: Lecha Wojtczaka (1990-1993), Bogusława Żernickiego (19931996), Jerzego Duszyńskiego (1996-2001), Małgorzaty Kossut (2001-2006), Leszka Kaczmarka (2007-2010), Andrzeja Wróbla (2011- ), jak również naukowo i organizacyjnie działających profesorów: Jolanty Barbary Barańskiej, Ewy J. Godzińskiej, Anny M. Grabowskiej, Andrzeja Grębeckiego, Barbary Grzelakowskiej-Sztabert, Marii Ł. Jerki-Dziadosz, Bożeny Kamińskiej-Kaczmarek, Anny J. Kosmal, Jacka M. Kuźnickiego, Ireny Łukaszewskiej-Bułat, Andrzeja P. Michalskiego, Katarzyny Nałęcz, Barbary Oderfeld-Nowak, Sławomira Pikuły, Wojciecha Rode, Ewy Sikory, Jolanty Skangiel-Kramskiej, Elżbiety Szeląg, Remigiusza L. Tarneckiego, Elżbiety Wyroby, Jolanty Zagrodzkiej-Szmagalskiej.

W roku 2002 z okazji pięćdziesięciolecia Polskiej Akademii Nauk wydano pracę zbiorową pt. „Placówki i komitety" ${ }^{\prime 20}$. Książka była dziełem ponad dwustu autorów, z których każdy miał za zadanie napisanie historii swej placówki według określonego układu i określonej objętości. Instytut Nenckiego przedstawili Maciej J. Nałęcz, ówczesny dyrektor i Kazimierz Zieliński, były wieloletni dyrektor.

Szczególnie istotnym elementem opisu każdej placówki było wskazanie najważniejszych osiągnięć. Lista przytoczona przez Macieja J. Nałęcza i Kazimierza Zielińskiego była długa i różnorodna.

„Najważniejsze osiągniecia: Sformułowanie koncepcji plastyczności neuronu (J. Konorski, 1948); odkrycie hamulcowej roli okolicy przedczołowej kory mózgowej (S. Brutkowski i in., 1956); odkrycie dwukierunkowego ruchu aksoplazmy (L. Lubińska, S. Niemierko i in., 1963); sformułowanie koncepcji, że za percepcję bodźców odpowiedzialne są pojedyncze neurony (J. Konorski, 1967); odkrycie, że mózg izolowany in situ zachowuje normalne funkcje (B. Żernicki, 1968); wykazanie, że rzęski pierwotniaków mogą pracować jak wici (L. Kuźnicki, 1970); wykrycie strukturalnych i fizjologicznych różnic w mechanizmach instrumentalnych reakcji obronnych (K. Zieliński, 1972); określenie roli podjednostek troponiny w regulacji skurczu mięśni (W. Drabikowski i in., 1970-1981); odkrycie obecności kalmoduliny we wszystkich tkankach ssaków, u pierwotniaków i śluzowców oraz wykazanie i scharakteryzowanie zmian konformacji k. pod wpływem wapnia (W. Drabikowski, J. Kuźnicki i in., 1976-1979); wykazanie wpływu potencjału powierzchniowego błon na kinetykę enzymów błonowych i transportu przez błony (L. Wojtczak, M. J. Nałęcz, 1976-1979); stworzenie ogólnej teorii skurczu kortykalnego i przedniej relaksacji w ruchu komórek ameboidalnych (A. Grębecki, 1981); określenie aferentnych i eferentnych połączeń kory przedczołowej u psa (A. Kosmal, 1981); odkrycie, że podanie gangliozydów zwierzętom z uszkodzonym mózgiem przyspiesza procesy kompensacyjne (B. Oderfeld-Nowak i in., 1982); odkrycie, że ciało migdałowate składa się z dwóch antagonistycznych części: pobudzeniowej i hamulcowej (E. Fonberg, 1986); wykazanie regulacyjnej roli przepuszczalności błony wobec protonów w magazynowaniu energii przez mitochondria (L. Wojtczak i J. Duszyński, 1986-1990); wykazanie zmian ekspresji genów w mózgu pod wpływem stymulacji fizjologicznej, w

\footnotetext{
${ }^{20}$ Placówki i komitety. Polska Akademia Nauk 1952-2002. Red. tomu L.
} Kuźnicki. Warszawa 2002, ss. 547. szczególności wykazanie, że glutaminian ma zdolności pobudzania ekspresji genów (L. Kaczmarek i in., 1988); oczyszczanie i scharakteryzowanie trzech mitochondrialnych nośników kwasów karboksylowych (M. J. Nałęcz i in. 1985-1989); wykazanie możliwości modulacji skurczu mięśni szkieletowych kręgowców przez fosforylację lekkiego łańcucha miozyny (I. Kąkol i in., 1982-1987); wykazanie, że synteza fostatydylocholiny jest regulowana przez wapń i zachodzi po wewnętrznej stronie siateczki śródplazmatycznej (J. Barańska i in., 1992); wykazanie, że czynność elektryczna w układzie wzrokowym o częstotliwości 15-30Hz jest podstawą procesu wagi (A. Wróbel i M. Bekisz, 1993); zidentyfikowanie funkcjonalnych rejonów cząsteczki kaldesmonu, regulatora skurczu mięśni gładkich (R. Dąbrowska i in., 1986-1997); wykazanie zmian ekspresji genów w mózgu w procesach uczenia (L. Kaczmarek i in., 19881992); udowodnienie, że śmierć neuronalna wywołana glutaminianem ma charakter apoptotyczny i towarzyszą jej zmiany ekspresji genów (Kamińska-Kaczmarek i in., 1994); wykazanie fizjologicznej roli karnityny w mózgu dla wzmożenia syntezy acetylocholiny (K. Nałęcz i in., 1995); odkrycie, że asymetria półkulowa mózgu ludzkiego ma charakter dynamiczny (A. M. Grabowska, 1996); wykrycie mechanizmów plastyczności somatycznej kory czuciowej u dorosłych zwierząt (M. Kossut i J. Skangiel-Kramska, 1999); opisanie mechanizmów przebudowy cytoszkieletu aktynowego podczas fagocytozy (A. Sobota i in., 1999); zidentyfikowanie konformacyjnych zmian w aktynie regulujących jej polimeryzację (H. Strzelecka-Gołaszewska i in., 1993-1999); wykrycie i opisanie układów przetwarzających sygnały świetlne na reakcje ruchowe u orzęsków (S. Fabczak i in., 2000); wykrycie, wyizolowanie i scharakteryzowanie kalcykliny i białka wiążącego kalcyklinę, CacyBP (J. Kuźnicki $\mathrm{i}$ in., 1987-2000).

Pracownicy, którzy zostali odznaczeni nagrodami państwowymi: J. Dembowski za prace w dziedzinie psychologii zwierząt (1949); J. Dembowski za całokształt pracy (1955); W. Niemierko za prace w dziedzinie biochemii owadów (1955); J. Konorski za badania w zakresie fizjologii mózgu (1964); W. Drabikowski za osiągnięcia w badaniu budowy i funkcji elementów kurczliwych mięśnia (1978); zespół B. Żernickiego za badania mechanizmów percepcji wzrokowej (1984).

Nagrody Prezesa Rady Ministrów otrzymali: L. Wojtczak za badania energetyki komórki zwierzęcej i transportu przez błony biologiczne (1996); B. Kamińska-Kaczmarek za najlepszą pracę habilitacyjną pt. Aktywacja czynnika transkrypcyjnego AP-1 w plastyczności neuronalnej (1998); M. Hetman za najlepszą pracę doktorską pt. Struktura genu katepsyny D myszy i jego ekspresja w doświadczalnych uszkodzeniach ośrodkowego układu nerwowego (1998).

Nagrodę Fundacji na rzecz Nauki Polskiej uzyskał L. Kaczmarek za prace nad regulacją ekspresji genów (2000).

Inne wyróżnienia pracowników Instytutu: Doktor honoris causa Univ. Of Pensylwania, Philadelfia, J. Konorski (1970); Doktor honoris causa Akademii Medycznej w Magdeburgu, L. Wojtczak (1988); Doktor honoris causa Rosyjskiej Akademii Nauk, L. Kuźnicki (2001); L. Kuźnicki Wiceprezesem PAN (1990-1992); L. Kuźnicki Prezesem PAN $(1993-1998)^{\prime \prime 21}$.

\footnotetext{
${ }^{21}$ Placówki i komitety ... dz. cyt., s. 79-81.
} 
Czynnikami wpływającymi na rozwój Instytutu w XXI wieku były nowe inicjatywy badawcze i związane $\mathrm{z}$ nimi inwestycje budowlane i aparaturowe.

21 kwietnia 2010 r. prof. Jerzy Duszyński podpisał umowę z konsorcjum dwóch firm na budowę Centrum Neurobiologii. Zgodnie $\mathrm{z}$ założeniem będzie ono składało się z dwóch „wież dobudowanych do istniejących skrzydeł budynku głównego. W jednej z wież zaplanowano salę wystawową (parter) i salę konferencyjną (I piętro). Całość prac zgodnie z planem miała się zakończyć do połowy grudnia 2011 r. Były to optymistyczne założenia.

Centrum Neurobiologii otworzono, łącząc to z Konferencją Bio-Imaging Poland, 15 listopada 2013 r. Na konferencji wystąpili wybitni specjaliści z zakresu badań obrazowych w naukach biologicznych i medycznych. W centrum zaopatrzonym w nowoczesną aparaturę znalazło miejsce pięć pracowni, którym otworzono możliwości prowadzenia nowoczesnych badań. Powstanie Centrum było jednocześnie uświetnieniem 95-lecia Instytutu i utworzeniem jednego $\mathrm{z}$ centralnych ośrodków badań obrazowych w Polsce.

Od roku 2009 do marca 2018 Instytutem Nenckiego kierował prof. Adam Szewczyk. Uroczystości związane ze stuleciem istnienia Instytutu będą przebiegać pod przewodnictwem kobiety. W wyniku konkursu nowym dyrektorem Instytutu została wybrana profesor Agnieszka Dobrzyń. Od roku 2007 kierownik Pracowni Sygnałów Komórkowych i Zaburzeń Metabolicznych. Instytut Nenckiego wkroczył w nowy etap rozwoju.

\title{
The century of Nencki Institute of Experimental Biology, PAS - the idea and will power
}

\section{Leszek Kuźnicki ${ }^{\bowtie}$}

\author{
Laboratory of Cytoskeleton and Cilia Biology, Nencki Institute of Experimental Biology, PAS, 3 Pasteura St., 02-093 Warszawa, Poland \\ e-mail: 1.kuznicki@nencki.gov.pl
}

Key words: history, Nencki Institute

\begin{abstract}
The Institute was founded in 1918, shortly after the re-establishment of Poland as an independent country. It was based on three pre-existing laboratories affiliated with the Scientific Society of Warsaw. The formation and development of the Institute was supported in part by a donation of Nadine Sieber-Shumova, a close co-worker of Marceli Nencki from Berne and St. Petersburg. Over the next two decades the Institute grew to become the leading biological research centre in Poland. The outbreak of World War II interrupted a period of its intensive expansion and achievement of scientific excellence in the field of experimental biology. After the turmoil of the war, during which over a dozen of the Institute's staff lost their lives, and its premises (including most of its 30.000 volume library)were destroyed, the surviving staff members (Jan Dembowski, Stefania Dembowska, Jerzy Konorski, Liliana Lubińska, Włodzimierz Niemierko and Stella Niemierko) re-established the Nencki Institute. In 1952, the Institute was incorporated into the newly founded Polish Academy of Sciences, and the Institute's director, Prof. Dembowski, became the first President of the Academy. During the period of 1953-55, a newly erected building at 3 Pasteur Street in Warsaw became the final home of the Nencki Institute. The research goals of the Nencki Institute are to arrive at molecular, cellular and systematic explanations of excitability, movement, development, memory, learning, behaviour, ageing and disease. All those tasks need to be both intellectually satisfying and relevant to problems of human health. Institute edit journal Acta Neurobiologiae Experimentalis. Directors from 1947: Jan Dembowski, Włodzimierz Niemierko, Jerzy Konorski, Kazimierz Zieliński, Maciej Jan Nałęcz, Jerzy Duszyński, Adam Szewczyk. At present Agnieszka Dobrzyń.
\end{abstract}

